\title{
DETERMINANTS OF REVERSE MORTGAGE USAGE IN MALAYSIA
}

\author{
Mohammed Ishaq Mohammed, M.Sc. \\ Faculty of Technology ManagementE Business, Universiti Tun Hussein Onn Malaysia \\ Faculty of Environmental Technology, Abubakar Tafawa Balewa University Bauchi \\ e-mail: immohd@atbu.edu.ng
}

\author{
Noralfishah Sulaiman, PhD \\ Faculty of Technology ManagementE Business \\ Universiti Tun Hussein Onn Malaysia \\ e-mail:nora@uthm.edu.my
}

\begin{abstract}
This study aims to identify the factors that influence a household's willingness to use reverse mortgage as a source of supplementary income in old age by adopting the original Theory of Planned Behavior (TPB) and extending it with three other additional constructs. Using a convenience sampling technique, a total of 391 valid questionnaires were used for data analysis. The data analysis was conducted using the SmartPLS software, version 3.2.6. The results suggest that the sense of attachment to a place, attitude, motive of bequest, social influence and perceived ability positively influence a household's willingness to use reverse mortgage, while financial behavior was found to negatively influence the willingness to do so. The findings of this study extend the application of the TPB to the domain of reverse mortgage product.
\end{abstract}

Key words: elderly, financial sustainability, housing, retirement, reverse mortgage.

JEL Classification: D03, R31.

Citation: Mohammed I. M., Sulaiman N., 2018, Determinnats of Reverse Mortgage Usage in Malaysia, Real Estate Management and Valuation, vol. 26, no. 3, pp. 05-23.

DOI: $10.2478 /$ remav-2018-0021

\section{Introduction}

The population of elderly people aged 60 years and over is projected to reach 2 billion by the year 2050 (United Nations Department of Economic and Social Affairs Population Division, 2013). It is estimated that a substantial share will be found in developing countries, which includes Malaysia. By the year 2020, the population of elderly people is expected to reach 10 percent of the country's population which is the global benchmark for identifying ageing nations. One of the challenges facing the elderly globally is the lack of sufficient finances to fund increased medical needs and other associated costs (HOE 2013; KUMAR, DivAKARUNI, SRI VENKATA 2008). This problem is further complicated given the fact that the sustainability of the social security systems, such as pension schemes and other welfare schemes that are meant to support the elderly past their active working age, is being doubted (COCCO, LOPES 2015; TOUSSAINT et al. 2012; ZIN, LEE, ABDUL-RAHMAN 2002).

Elderly Malaysians are not an exception to this problem. The inadequacy of savings upon retirement has been identified as the main challenge facing this group of individuals (ABD SAMAD, MANSOR 2013; HAMID 2015; MOHAMMED, SUlAIMAN 2017b). Studies have shown that they are facing challenges in terms of financial sustainability, adequacy of retirement income and healthcare financing as a result of increasing life expectancy, changing family structure and other socio-economic changes 
being witnessed in the country (Help Age International \& UNFPA, 2012). A report indicated that retirees in Malaysia use up an average RM150,000 (\$37,000 approximately) of their Employee Provident Fund (EPF) savings in the first three to five years of retirement (Employee Provident Fund, 2015). This is alarming considering that the EPF is the most popular retirement savings scheme in the country, covering private sector employees and public-sector employees that are not eligible for the public pension scheme. Furthermore, an alternative means by which the elderly could avoid the effect of financial insecurity in later life is by putting away savings when young. Lamentably, however, Malaysians are not saving enough to enable them to cushion the effect of income shocks later in life (LOKE 2013). This is further verified by a recent report which indicated that 90 percent of urban households and 86 percent of rural households in the country have zero savings (ALAVI 2013). Similarly, while family traditionally serves as an important source of support to the elderly among the Malaysians, recent evidence points to the gradual decline of this long-lasting Asian legacy among many as a result of modernization (ALAVI 2013).

Notwithstanding the risk of financial insecurity associated with the elderly, evidence has shown that they are "asset-rich". It was argued that, by virtue of the enormous housing wealth in their possession, elderly people can cushion the effect of old-age poverty by turning the accumulated home equity locked in their housing wealth into cash by using reverse mortgage or other equity release products (HANewald, Post, SHerRis 2016; ONG 2008; RASMUSSEN, MegbOlugbe, MorGan 1995; SHAN 2011). In Malaysia, real estate has been established to constitute the largest single asset for the majority of households, irrespective of financial status (The World Bank, 2014). The national home ownership rate in 2010 was 74.5 percent (Department of Statistics Malaysia, 2012). These scenarios suggest that elderly Malaysian people fall within the cash-poor-asset-rich classification. Therefore, in an attempt to explore the feasibility of developing a reverse mortgage market in Malaysia, this study aimed to identify the factors that influence people's willingness to use reverse mortgage as a source of supplementary income in old-age.

\section{Literature review}

Reverse mortgage is one of the many financial products that enable consumption smoothing over the life cycle. The general name for this product class is "home equity release products". Home equity release products have generally been promoted as a means of tapping the equity trapped in residential houses (KUMAR 2013). This especially pertains to retired elderly homeowners, whose debtfree properties form the major part of their net assets (ONG et al. 2015). The continuing increase in the cost of providing old-age related payments and services amidst a persistent global economic crisis is linked to the growing popularity of real estate assets as a potential source of income capable of supplementing the dwindling pension fund and various social security funds in many countries (DOLING 2010; HAFFNER, ONG, WOOD 2015). Being the most significant asset among the majority of households, the primary home is regarded as a store of wealth that can be used to augment the income needs of the elderly after retirement. This led to the emergence of financial products that make it possible for homeowners to access the illiquid wealth trapped in their residential real estate. These financial products are generally termed home equity release products.

Home equity release products enable home owners the flexibility of consuming the accumulated equity in their housing wealth without necessarily moving out of the property. This can be done through a lease-back arrangement, where an owner sells his property to a buyer, then rents the property back, thus becoming a renter. It can also be in the form of the physical subdivision of a property to create two separate units which makes it possible for one of the units to be rented out or even sold. Similarly, other alternative products allow the homeowner to sell the property to a third party with the condition that a lump sum or annuity payment will be advanced to him/her until his/her death upon which the ownership of the property is transferred to the buyer. In some jurisdictions, banks and other financial institutions introduced some financial products that offer homeowners access to housing equity while maintaining the ownership of their residential properties, popular among which are equity withdrawal and reverse mortgage (MAYER, SIMONS 1994).

Reverse mortgage has been described as a form of annuity to the homeowner for the length of time he/she remains in the home (KUMAR 2013). It is designed for elderly homeowners to enable them to access their accumulated home equity while continuing to live in their homes (REED, GIBLER 2003). In contrast to a conventional forward mortgage, where periodic payment is made to the lender, in a reverse mortgage contract, the payment is made by the lender to the homeowner. The loan principal 
and the accumulated interest are repaid when the borrower sells the home, moves permanently or dies (KUMAR 2013; MAYER, SIMONS 1994). The amount of money a borrower can access in a reverse mortgage contract is a function of the borrower's age, the value of the property and the prevailing interest rate (REDFOOT, SCHOLEN, BROWN 2007).

The product is designed to provide elderly people who are asset-rich-cash-poor and who require additional funds to finance their medical needs, children's education, home improvement, leisure, bills and other necessities that may arise during the years remaining after their active working life. Unlike the conventional forward mortgage, where the borrower must surrender collateral to which recourse can be made upon default, a reverse mortgage loan does not require any form of collateral to be surrendered by the borrower. Repayment of the loan principal and the accumulated interest is made from the proceeds realized from selling the home after the death of the borrower or when he/she decides to permanently move out of the home to a care facility. The loan can be accessed through regular monthly payments, a lump sum payment, or a line of credit, or a combination of these options.

The growth and sustainability of a reverse mortgage product market is linked to a set of interrelated factors as evidenced in literature. Although there are no studies specifically concentrated on investigating the influence of behavioral factors on the decision to make use of reverse mortgage, some studies hinted to the possible effect of behavioral factors on an individual's decision to use or apply for reverse mortgage. For instance, a study in Italy reported that risk/uncertainty-related elements are significantly correlated with people's interest in reverse mortgage (FORNERO, ROSSI, BRANCATI 2011). This is buttressed by another study where it was found that debt aversion, perception of home equity as savings, high origination costs, and unexpected expenses are the reasons behind the slow growth of the reverse mortgage market (LEE, CHEN, SO-DE SHYU 2015).

In a different study that analyzed the regional differences in demand for reverse mortgage in Beijing and Hangzhou, China, it was revealed that, even though the respondents own their houses and their monthly income is below the disposable income level, they show weak interest in applying for reverse mortgage to supplement their monthly income (ZHOU 2014). The resultant weak interest in reverse mortgage was attributed to the attitude of the elderly towards the product, as it is seen as a last resort source of finance to be used only in emergency situations. Respondents also showed a strong motive to leave houses to their children. It is further found that, in Beijing, elderly people suffering from health problems are more likely to apply for reverse mortgage than their healthy counterparts, because of the increase in medical expenses.

FRATANTONI (1999) explored the determinants of reverse mortgage choice using stochastic dynamic programming techniques and multinomial logistic regression by adopting the Home Equity Conversion Mortgage data set. The result of the simulation shows that elderly people who are mainly concerned with the impact of unavoidable expenditure shocks on their standard of living, reveal a higher probability of using a line of credit plan than either tenure or term plans. The choice of a line of credit plan is based on the fact that it gives the borrower access to a large sum of money, rather than adding an additional fixed component to existing income.

An Individuals' decision to consider applying for reverse mortgage has also been found to be influenced by the level of his or her financial awareness and involvement, which describes the general financial behavior of individuals. This is evident in a recent study in which (DAVIDOFF, GERHARD, POST 2017) discovered that the lack of product knowledge significantly affects the demand for reverse mortgage. They pointed out that demand for a reverse mortgage product can be reasonably increased by reducing the inherent complexity in the product design. Similarly CHOU, CHOW and CHI (2006), in a study that aimed at investigating the feasibility of using reverse mortgage as alternative option for generating retirement income for asset-rich-cash-poor elderly people in Hong Kong, revealed that the possession of stocks, bonds or funds was positively related to the willingness to apply for a reverse mortgage. The findings from this study further highlighted the role financial awareness can play in an individual's decision to apply for reverse mortgage, since the respondents that showed a strong willingness to apply for the product indicated that they have one or more financial products in their possession, thus indicative of financial market awareness.

Moreover, many studies on the reverse mortgage market highlighted the possible roles of some social, economic and cultural factors in determining people's interest and/or decision to use reverse mortgage products. Factors such as the bequest motive, attachment to one's home, ethnicity and/or 
race, intergenerational transfer and expectations of family members have been found to influence an individual's interest in applying for a reverse mortgage loan. For example, there is evidence that young people's high expectation for inheritance was found to negatively affects their willingness to approve of their parents' application for a reverse mortgage (YOO, KOO 2008). Moreover, in a study that investigates the feasibility of implementing reverse mortgage for asset-rich-cash-poor older adults in Hong Kong, it was found that living arrangements, the desire to leave ones property to descendants and intergenerational transfers received from children and grandchildren negatively affect people's desire to apply for reverse mortgage (SAU PO CENTRE ON AGEING, 2010).

In another study that explored the relationship between family and community ties and the demand for reverse mortgage in the USA, a fairly strong relationship between family and community ties and interest in reverse mortgage was established. It was discovered that a higher incidence of young people out-migration tends to increase demand for reverse mortgage, while old-out-migration tends to reduce demand for this product (KNAPP 2001). Furthermore, CHINLOY and MegBolugbe (1994) identified the desire to be close to family and friends, emotional attachment to the home and financial factors as determining the use of reverse mortgage among the elderly. In another study, FORNERO et al. (2011), using the Discrete Choice Model and Ordered Probit, analyszd the 2007 UniCredit Survey dataset to investigate the underlying factors determining interest in the reverse mortgage product in Italy. The result revealed that homeowners who are less attached to their home and have no fear of liquidating it are more likely to be interested in reverse mortgage. In addition, the result also indicated that risk/uncertainty-related elements have a significant correlation with interest in reverse mortgage, while negative expectations about one's post-retirement standard of living were found to be a statistically significant predictor to interest in reverse mortgage. On the other hand, no significant relationship was found between financial literacy and interest in the reverse mortgage product among the respondents. Similarly, LEE et al. (2015) found that the slow speed at which the elderly utilize innovative products, aversion to placing a lien on one's home, the perception of home equity as savings, high origination costs and unexpected expenses are among the factors that affect the growth in the demand for a reverse mortgage product.

These studies highlighted the role of behavioral factors, such as attitude, the bequest motive, social influence, financial behavior, and attachment to a place as possible determinants of reverse mortgage use. However, in almost all previous studies, these factors were considered independently or in combination with other economic factors. It is, therefore, worthwhile to combine these factors in a single model to determine their collaborative effect on an individuals' intention to use reverse mortgage.

\subsection{Hypotheses development}

The willingness of individuals to take up a reverse mortgage is modelled according to the Theory of Planned Behavior (TPB). The TPB has recently become a popular theory used to study individual financial decision-making (AHMAD 2014; Alam et al. 2012; Amin 2013; AmIN, AbDUl RAHMAN, ABDUL RAZAK 2014; HANUdiN et al. 2011; KENNEDY 2013; PUTIT, JoHAN 2015; TAIB, RAMAYAH, RAZAK 2008). Reverse mortgage-related literature highlighted that an individuals' decision to participate in a reverse mortgage transaction is influenced by a set of behavioral factors, such as attitude, societal norms, self-control, the bequest motive, a sense of attachment to a place/neighborhood and financial behavior, among other factors. Using the original TPB constructs and three additional constructs that are deemed necessary in predicting the use of reverse mortgage, a Reverse Mortgage Use Intention Model was proposed (ReMUIM) (MOHAMMED, SUlAimAn 2017a). The justification for including the three new constructs was based on the facts that the TPB is open to the inclusion of additional predictors if it is evident that such predictors have a significant contribution to predicting intention (AJZEN 1991). The proposed model constitutes seven (7) constructs. Four of the constructs, Perceived Ability (PA); Social Influence (SI); Attitude (ATT) and Reverse Mortgage Use Intention (RMUI) convey the same meaning applied to the original TPB constructs. On the other hand, the remaining three constructs, Bequest Motive (BM), Sense of Place Attachment (SPA), and Financial Behavior (FB) were additional constructs identified in the literature as potential predictors of the willingness for reverse mortgage use.

Figure 1 shows the theoretical model of the research. A detailed explanation of the constructs and their relationships is presented. The purpose of the explanation is to offer a much clearer view on the 
theoretical model by contextualizing the constructs in line with the distinctiveness of the current study and develop working hypotheses for further empirical verification.

\subsubsection{Reverse mortgage use intention (RMUI)}

Although there is not a perfect relationship between behavioral intention and actual behavior, intention can be used as a proxy measure of behavior. Behavioral intention is a good predictor of the actual usage of an application or system (VENKATESH, DAVIS 2000). It may be a natural conclusion then, that any factors influencing behavior can indirectly influence intention (SLATTEN 2010). In this study, the degree of willingness to use reverse mortgage is examined in association with the other constructs. It is expected that higher willingness will translate to higher actual use, while lower willingness will result in low or non-use.

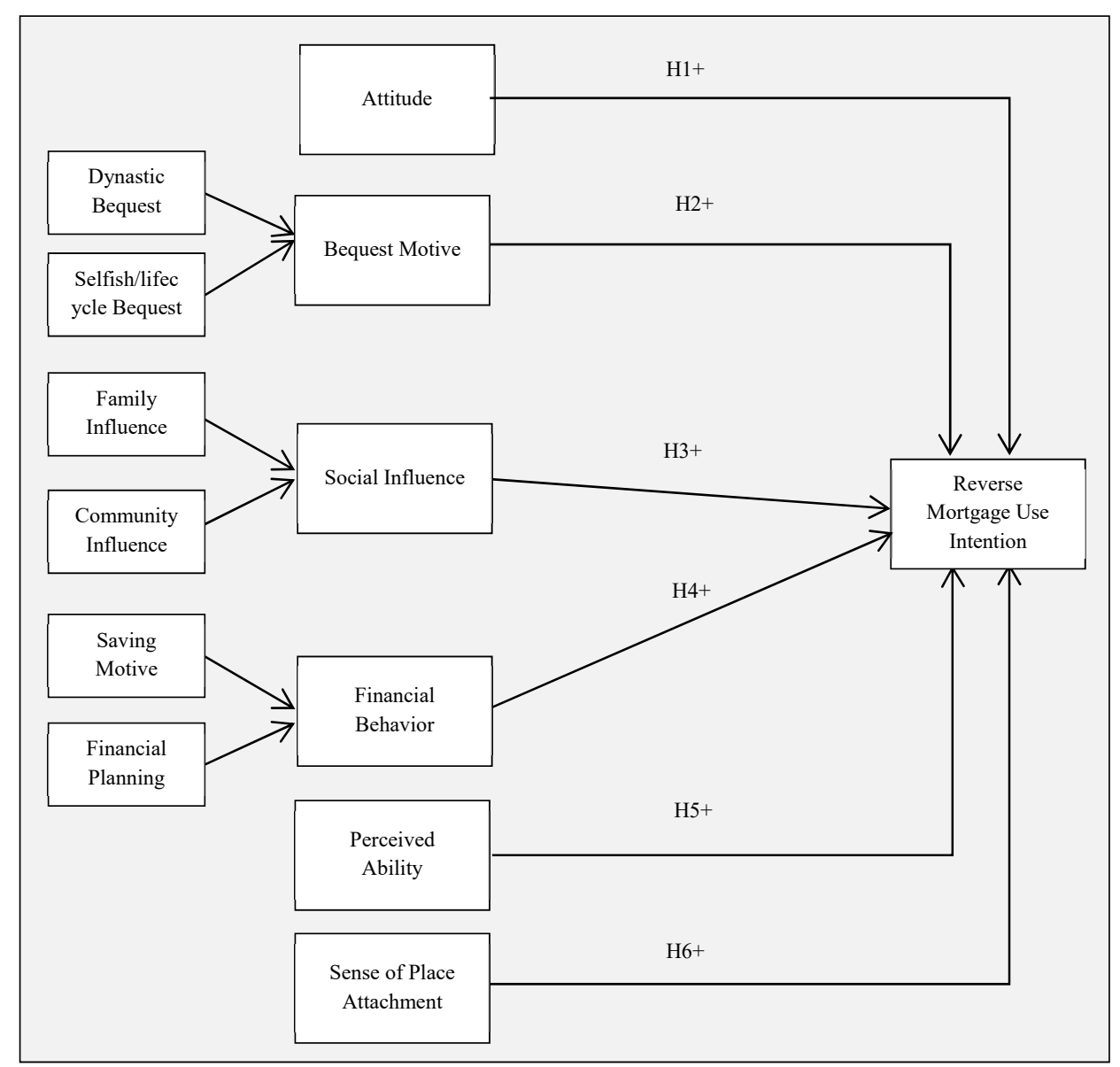

Fig. 1. Reverse Mortgage Use Intention Model (ReMUIM). Source: own study.

\subsubsection{Attitude (ATT)}

The attitude-behavioral intention relationship implies that people form intentions to perform behavior towards which they have positive effect. Attitude is a consumer's perception regarding the outcome of an experience (DAVIS, BAGOZZI, WARSHAW 1992). Therefore, it is expected that, when potential reverse mortgage borrowers perceive the product as useful, beneficial, a value for the money etc., they are more likely to accept its use. On the other hand, if they perceive reverse mortgage as not useful, risky, complex, etc., there is an increased likelihood of them not accepting or using the product. Therefore, the inter-relationship between attitude and the intention to use reverse mortgage are important to examine. In view of the aforementioned, it is hypothesized that: 


\section{H1: Attitude significantly affects reverse mortgage use intention}

\subsubsection{Bequest motive (BM)}

Bequest motive is an additional construct introduced in the original TPB. Its inclusion as a construct in this study is based on the expectation that it will influence an individual's willingness to use a reverse mortgage product. Literature on reverse mortgage demand indicated that an individual's desire to leave behind assets to heirs upon their death might influence peoples' willingness to apply for a reverse mortgage product (CAPLIN 2001; GOTMAN 2011; LEVITON 2002). Studies on bequest and inheritance in Malaysia revealed that people hold different bequest motives with regards to the sharing of their assets. Studies have revealed evidence of selfish life-cycle, altruistic, dynastic, social norm and traditional bequest motives among Malaysians (ALAVI 2013; ALMA'AMUN 2012; CHUAN, SEONG, CHAU 2014). It is, therefore, worthwhile to include bequest motive as an additional construct in the TPB in order to investigate its influence on the willingness of Malaysians to use a reverse mortgage product. It is therefore hypothesized that:

\section{H2: Bequest motive significantly affects reverse mortgage use intention}

\subsubsection{Social influence (SI)}

Social influence is used in this context to convey the socio-cultural expectations that could affect an individual's willingness to use reverse mortgage. According to the TPB, other people's expectations regarding an individual's action influence intentions, both positively and negatively. Previous studies on reverse mortgage indicate that the decision to apply or use reverse mortgage could probably be influenced by family members, community and financial advisers (Yoo \& Koo, 2008). It is anticipated that when family members support an individual's decision to apply for a reverse mortgage loan, it will affect intention positively and vice-versa. Similarly, culture is expected to influence an individual's decision to use reverse mortgage. Cultural norms and the system of beliefs, such as bequest and intergenerational practices, may influence one's willingness to use reverse mortgage. Expectations to adhere to certain laid down rules in administering one's property could also affect the intention to use reverse mortgages. Community and family expectations to bequeath one's property to his or her offspring in line with the concept of reciprocity (KOLM 2006; NICIŃSKA 2013) could influence the decision regarding reverse mortgage. Based on the aforesaid, this study hypothesized that:

\section{H3: Social influence significantly affects reverse mortgage use intention}

\subsubsection{Financial behavior (FB)}

In financial behavior literature, four major domains of financial behavior were identified to include managing money, planning ahead, choosing products and staying informed (KEMPSON, COLLARD, MOORE 2005). Effective engagement in these behaviors to improve one's financial well-being leads to positive or desirable financial behavior, while their ineffective use translates to negative or undesirable financial behavior (XIAO, SORHAINDO, GARMAN 2006). Thus, it is expected that an individual's financial behavior will influence the decision to apply for a reverse mortgage. It is expected that those individuals who interact with other forms of financial products will be more likely to enter into a reverse mortgage transaction than those who are not involved in such, as such it is hypothesized that:

\section{H4: Financial behavior significantly affects reverse mortgage use intention}

\subsubsection{Perceived ability (PA)}

Perceived ability reflects the perceived belief of performing the behavior in question. In the context of this research, the likelihood of individuals applying for a reverse mortgage in the future depends on their conviction about the opportunities (availability of reverse mortgage products, desire to age-inplace), resources (home ownership, information and knowledge), and barriers (risk aversion, debt aversion), associated with their action. Similarly, as mentioned earlier, individual's perceived control is partially affected by past experience and second-hand information about the behavior. It is assumed that previous experience in financial and investment decisions, such as buying annuity product, taking up mortgage, or investing in shares, will influence the willingness to use reverse mortgage. 
Evidence in reverse mortgage literature indicates that low income, attachment to one's home, home ownership, previous investment decisions, risk averseness, and counselling influences interest in reverse mortgage. Therefore, it is hypothesized that:

\section{H5: Perceived ability significantly affects reverse mortgage use intention}

\subsubsection{Sense of place attachment (SPA)}

According to HASHEMNEZHAD, HEIDARI and HOSEINI (2013), sense of place is the relationship between man, his image and environmental characteristics. Place attachment has been described as the positive bond that exists between groups or individuals and their environment (JORGENSEN, STEDMAN 2001). One of the conditions in a reverse mortgage contract is that the borrower ought to live in the house permanently, until death. Findings from reverse mortgage studies implied that those individuals who are highly attached to their environment are the most attracted to reverse mortgage while those who anticipated moving out showed less interest in taking out a reverse mortgage (YOO, KOO 2008). Considering this, the addition of a construct that measures the degree of place attachment to the original TPB is important because it is expected that an individual's willingness to use reverse mortgage will be affected by the degree to which he or she plans to remain in the house or community. Thus, it is hypothesized that:

\section{H6: A sense of attachment to a place significantly affects reverse mortgage use intention}

\section{Methodology}

\subsection{Research instrument}

The indicators that measured the seven (7) constructs were generated through literature review and by modifying the original statements in the TPB questionnaires to reflect the specificity and suit the context of the present study. The questionnaire was designed in a Likert-scale type rating scale. This scale type was chosen because it provides ordinal level measures of multiple-indicator measurements of behavioral, attitudinal and psychological concepts which provide greater flexibility for data analysis (LEE 2005; BABBIE 2001; MILLER 1991). Moreover, many studies have used the Likert-scale to assess beliefs, attitude and behavior (FISHBEIN, AJZEN 1975). The questionnaire assessed the intensity and direction of the respondents' agreement or disagreement with a series of statements that measure attitude (ATT), social influence (SI), perceived ability (PA), bequest motive (BM), and the sense of place attachment (SPA) on a five-point, i.e. "strongly disagree" (1) to "strongly agree" (5), scale. Reverse mortgage use intention (RMUI) was assessed using a five-point rating scale of "extremely unwilling" (1) to "extremely willing" (5), while financial behavior (FB) was assessed using a fivepoint rating scale of "never" (1) to "always" (5). Table 1 shows the constructs, indicators and the various sources they were obtained from. A factor analysis using Principal Axis Factoring (PAF) was conducted on 53 items using oblique rotation based on the direct oblimin option with a representative sample of 102 respondents. The KMO returned a value of .750 which falls within the recommended threshold of .50 (FIELD 2009). Bartlette's test of sphericity $X^{2}(820)=3650.095, p<0.000$ confirmed that the determinant of the correlation matrix is a non-zero. The analyses resulted in retaining 41 items out of the 53 items that were originally included in the first draft of the questionnaire. The factor analysis result indicated that the 41 items can be appropriately clustered into 10 factors, which were labelled: Reverse Mortgage Use Intention, Family Influence, Saving Behavior, Dynastic Bequest, Attitude, Sense of Place Attachment, Perceived Ability, Community Influence, Financial Planning, and SelfishLifecycle Bequest. The results of reliability analysis showed that all the scales were reliable. The Cronbach's Alphas of the scale range from .790 to .945, while the corrected-item-total correlations range from .610 to .904 , which leads to the conclusion that the questionnaire can be used to gather information from the larger sample in the main survey (MOHAMMED, SULAIMAN, ADAMU, 2018.).

Table 1

Operationalization of constructs

\begin{tabular}{|c|c|c|}
\hline Construct & Indicators & Sources \\
\hline Attitude (ATT) & $\begin{array}{ll}\text { - } & \mathrm{RM} \text { is a good deal } \\
\text { - } & \mathrm{RM} \text { sounds complex }\end{array}$ & $\begin{array}{l}\text { Ajzen (1991); Chavez \& Sandstrom (2013); } \\
\text { Davidof f et al., (2014); Caplin (2000); }\end{array}$ \\
\hline
\end{tabular}




\begin{tabular}{|c|c|c|}
\hline Construct & Indicators & Sources \\
\hline & $\begin{array}{l}\text { - } \mathrm{RM} \text { is risky } \\
\text { - } \mathrm{RM} \text { will be useful } \\
\text { - } \mathrm{RM} \text { is full of promise } \\
\text { - } \mathrm{RM} \text { is unrealistic } \\
\text { - } \quad \text { Engaging in } \mathrm{RM} \text { transaction } \\
\text { is a morally bad idea }\end{array}$ & $\begin{array}{l}\text { Haizhen (2014); Doling (2010); Fornero et } \\
\text { al., (2011); Lee et al., (2015); Naumanen \& } \\
\text { Ruonavaara (2015); Ong et al., (2013); } \\
\text { Terry \& Gibson (2006) }\end{array}$ \\
\hline $\begin{array}{l}\text { Social } \\
\text { Influence (SI) }\end{array}$ & $\begin{array}{l}\text { - My children will approve of } \\
\text { me entering into a reverse } \\
\text { mortgage transaction } \\
\text { My spouse will support me } \\
\text { if I decide to enter into a } \\
\text { reverse mortgage transaction } \\
\text { - My siblings will support me } \\
\text { if I decide to enter into } \\
\text { reverse mortgage } \\
\text { My parents will not care if I } \\
\text { decide to enter into a reverse } \\
\text { mortgage transaction } \\
\text { My peers' opinion will } \\
\text { influence my decision to } \\
\text { enter into a reverse mortgage } \\
\text { transaction } \\
\text { My financial advisor's } \\
\text { opinion will greatly } \\
\text { influence my decision to } \\
\text { enter into a reverse mortgage } \\
\text { transaction } \\
\text { I will consider my } \\
\text { community's norms and } \\
\text { values before I apply for a } \\
\text { reverse mortgage }\end{array}$ & $\begin{array}{l}\text { Ajzen (1991); Yoo \& Koo (2008); Haizhen } \\
\text { (2014); AARP (2010); Shan (2011); Terry \& } \\
\text { Gibson (2006); Costa-Font et al., (2010) }\end{array}$ \\
\hline $\begin{array}{l}\text { Perceived } \\
\text { Ability(PA) }\end{array}$ & $\begin{array}{l}\text { - I own my house free of any } \\
\text { housing loan debt } \\
\text { - I have almost paid off my } \\
\text { housing loan } \\
\text { - I am free to enter into a } \\
\text { Reverse Mortgage } \\
\text { transaction } \\
\text { - I have absolute control over } \\
\text { my house } \\
\text { - I like being financially } \\
\text { independent } \\
\text { - I like investing in new } \\
\text { financial products } \\
\text { - I trust my financial } \\
\text { institution }\end{array}$ & $\begin{array}{l}\text { Luiz \& Stobie (2010); Reifner et al., (2007); } \\
\text { Gibler \& Reed (2003); Frantatoni (1999); } \\
\text { Chou et al., (2006); Williams \& Kao (1997) }\end{array}$ \\
\hline $\begin{array}{l}\text { Bequest Motive } \\
\text { (BM) }\end{array}$ & $\begin{array}{l}\text { I plan to leave my house as a } \\
\text { bequest to my children } \\
\text { - I will definitely leave my } \\
\text { house to my children } \\
\text { - My children expect me to } \\
\text { leave my house for them to } \\
\text { inherit } \\
\text { - I will be ashamed not to }\end{array}$ & $\begin{array}{l}\text { Alma'mun (2012); Chuan, Seong \& Chau } \\
\text { (2012); Chuan et al., (2011); }\end{array}$ \\
\hline
\end{tabular}




\begin{tabular}{|c|c|c|}
\hline Construct & Indicators & Sources \\
\hline & $\begin{array}{l}\text { leave my house to my } \\
\text { children to inherit } \\
\text { - I have no children to leave } \\
\text { my house to } \\
\text { - My children can only inherit } \\
\text { my house if they help me } \\
\text { while I am alive } \\
\text { My children will be/are } \\
\text { already self-sufficient and do } \\
\text { not care if I sell my house }\end{array}$ & \\
\hline $\begin{array}{l}\text { Sense of Place } \\
\text { Attachment } \\
\text { (SPA) }\end{array}$ & $\begin{array}{l}\text { - } \quad \text { My house meant a lot to me } \\
\text { - } \quad \text { a am very attached to my } \\
\text { neighborhood } \\
\text { - } \quad \text { I identify strongly with my } \\
\text { neighborhood } \\
\text { - I have a special bond with } \\
\text { my neighborhood and the } \\
\text { people living in the area } \\
\text { - I derive more pleasure from } \\
\text { living in my house than any } \\
\text { other house } \\
\text { - I am completely satisfied } \\
\text { with my accommodation } \\
\text { Living in my neighborhood } \\
\text { is more important than in } \\
\text { other neighborhoods; I will } \\
\text { not relocate from this } \\
\text { neighborhood }\end{array}$ & $\begin{array}{l}\text { Kyle et al. (2004); Jorgensen \& Stademan } \\
\text { (2006); }\end{array}$ \\
\hline $\begin{array}{l}\text { Financial } \\
\text { Behavior (FB) }\end{array}$ & $\begin{array}{l}\text { - I have contributed money to } \\
\text { retirement fund } \\
\text { - I bought bonds, stocks or } \\
\text { mutual fund } \\
\text { - I saved for a long-term goal } \\
\text { such as a car, education, or } \\
\text { home } \\
\text { - I maintained an emergency } \\
\text { savings fund } \\
\text { - I saved money from every } \\
\text { monthly income } \\
\text { - I make minimum payment } \\
\text { on loans } \\
\text { - I obtained or maintained } \\
\text { adequate health insurance } \\
\text { - I obtained or maintained } \\
\text { adequate property insurance } \\
\text { - I have obtained or } \\
\text { maintained adequate life } \\
\text { insurance }\end{array}$ & $\begin{array}{l}\text { Chen \& Jensen (1987); Xiao, Tang \& Shim } \\
\text { (2008); Naumanen \& Ruonavaara (2015); } \\
\text { Shan (2011); }\end{array}$ \\
\hline $\begin{array}{l}\text { Reverse } \\
\text { mortgage Use } \\
\text { intention } \\
\text { (RMUI) }\end{array}$ & $\begin{array}{l}\text { - I am willing to use RM to } \\
\text { supplement my existing } \\
\text { source of income } \\
\text { - I am willing to use RM for } \\
\text { house upgrades / repairs }\end{array}$ & $\begin{array}{l}\text { Ajzen (1991); Haizhen (2014); Fornero et } \\
\text { al. (2011); Costa-Font et al., (2010); Chou et } \\
\text { al., (2006); Chen \& Jensen (1987) }\end{array}$ \\
\hline
\end{tabular}




\section{$\$$ sciendo}

\begin{tabular}{|c|c|c|}
\hline Construct & Indicators & Sources \\
\hline & $\begin{array}{l}\text { - I am willing to use RM to } \\
\text { pay off existing mortgage } \\
\text { - I am willing to use RM to } \\
\text { pay off other debts } \\
\text { - I am willing to use RM to } \\
\text { pay medical bills } \\
\text { - I am willing to use RM to } \\
\text { fund leisure activities } \\
\text { (vacation, tourism) } \\
\text { - I am willing to use RM to } \\
\text { pay children/family } \\
\text { expenses } \\
\text { - I am willing to use RM to } \\
\text { settle unforeseen financial } \\
\text { needs }\end{array}$ & \\
\hline
\end{tabular}

Source: own study.

\subsection{Research design and data collection}

A convenience sampling strategy was used to administer questionnaires to a total of 432 households in Batu Pahat local council, Johor state. The researcher and three field assistants administered the questionnaire to the heads of the households or other members of the households when the head was not present. A total number of 421 questionnaires were retrieved out of which 391 were found duly completed and, therefore, used for further analysis. The sample size was deemed adequate for PLSSEM analysis in respect to the theoretical model of the current research. According to G-power software, the minimum sample required was 146 respondents. This was achieved based on 6 predictor variables with 0.95 power, an effect size of 0.15 and error probability of 0.05 .

\subsection{Data analysis}

The data analysis was done using Partial Least Squares software, SmartPLS version 3.2.6. PLS-SEM was used in the analysis because the data collected failed to satisfy the normality assumption, which is one of the requirements for CB-SEM analysis. Preliminary analysis on the data revealed that both the standardized skewness and kurtosis values tested at a 5\% level of significance exceeded the critical value of \pm 1.96 threshold as recommended by (HAIR et al. 2010; TABACHNICK, FIDELL 2013). The theoretical framework of this research was made up of six exogenous constructs and one endogenous construct. Three of the six exogenous constructs were modelled as higher-order constructs, each formatively linked with two lower-order constructs. The relationship between all the constructs (both first-order and second-order) with their respective indicators was reflective. Thus, following the recommendation of BECKER, KLEIN and WETZELS (2012), a reflective-formative type of hierarchical latent variable model with a repeated-indicator "Mode A" method was used to model and estimate the hierarchical latent variable model of the research model. Following the recommended PLS-SEM two-staged analytical process (HAIR et al. 2014), the measurement model was assessed for validity and reliability, which was followed by structural model evaluation. In order to test the significance of the path estimates, effect size and coefficient of determination, 5000 bootstrap sampling was run based on the centroid method and no-sign change criteria (HAIR et al. 2014).

\section{Results}

\subsection{Demographic characteristics of respondents}

Analysis of the socio-demographic characteristics of the respondents shows that 43 percent were in the 15-29 year-old age category, while 32 percent were in the 30-44 year-old age group. About 20 percent indicated that they were aged between $45-59$, while only 5 percent fell within the age bracket of 60 years and over. The gender distribution of the respondents indicated that about 53 percent were males, while the remaining 47 percent were females. More than half of the respondents were married, while 46 percent were single. The majority of the respondents were Malays (65 percent), with about 23 percent Chinese, and only 8 percent - Indian; about 5 percent of the respondents did not indicate their 
ethnic affiliation. The religious inclination of the respondents showed that about 76 percent were Muslims, 16 percent - Buddhist, and about 6 percent are either Christians or Hindus. The educational background of the respondents showed that more than half (60 percent) possessed tertiary education, 34 percent secondary education, while only about 6 percent indicated that they had completed only primary education. The income status of the respondents indicated that 48 percent earned between RM1000-RM2999 per month. Slightly above a quarter earned less than RM 1000 per month. Meanwhile, about one-third showed that they earned between RM3000-RM9999 per month. Salary and wages were indicated as the major source of income by the respondents (about 80 percent). Eight percent of the respondents indicated a Mutual Fund as their major source of income, while about 4 percent mentioned annuity/insurance as their main source. About 9 percent relied on either pension, rent or stock/shares as sources of income. Regarding the adequacy of their income, more than 50 percent of the respondents indicated that their income was enough for basic needs only. About one quarter indicated that their income is adequate for savings, while about 13 percent indicated that their income is not adequate.

\subsection{Assessment of measurement model}

The recommended practice for assessing a hierarchical latent variable model involved the assessment of both the first-order and the second-order constructs to establish construct validity (BECKER et al., 2012; HAIR et al., 2014). Construct validity shows the extent to which the respective indictors represent their underlying latent variables. In addition, to establish construct validity, the indicators in the measurement model must meet the requirement for convergent and discriminant validity. Convergent validity measures the extent to which indicators of the same concept are correlated, while discriminant validity measures the degree of uniqueness of a construct in relation to other constructs (HAIR et al. 2014; YEAP, RAMAYAH, SOTO-ACOSTA2016).

The recommendation for assessing convergent validity involves meeting the criteria for indicator reliability by examining the indicator loadings, composite reliability, and the average variance extracted (AVE). For a construct to achieve convergent validity, the literature recommended the values of 0.7 and above for both indicator loading and composite reliability, and 0.5 and above for AVE (HAIR et al. 2014). Discriminant validity was assessed by examining the Fornell-Larcker criterion and the heterotrait-monotrait (HTMT) ratio of correlations (ALI, KIM, RYU 2016; HENSELER, RINGLE, SARSTEDT, 2015).

Table 2

Weights of the first-order constructs on the respective second-order constructs

\begin{tabular}{llll}
\hline Second-order construct & First-order construct & Weight & t-value \\
\hline \multirow{2}{*}{ Bequest Motive } & Dynastic Bequest & 0.623 & 32.311 \\
\cline { 2 - 4 } & Selfish-lifecycle Bequest & 0.548 & 30.408 \\
\hline \multirow{2}{*}{ Social Influence } & Family Influence & 0.619 & 51.431 \\
\cline { 2 - 4 } & Community Influence & 0.496 & 39.830 \\
\hline \multirow{2}{*}{ Financial Behavior } & Saving Motive & 0.511 & 31.516 \\
\cline { 2 - 4 } & Financial Planning & 0.645 & 30.897 \\
\hline
\end{tabular}

Source: own study.

\subsection{Validity of first-order constructs}

Table 2 shows the weights of the first-order constructs on their respective second-order constructs. The weights are all significant, thus meeting the threshold as recommended in (HAIR et al. 2014). The first-order constructs were also assessed for multi-collinearity. The essence of multi-collinearity assessment in PLS-SEM analysis is to ensure that the estimation of the path coefficients between the exogenous constructs and the endogenous construct are unbiased (HAIR et al, 2014). Multi-collinearity diagnosis in PLS-SEM involves the examination of the variance inflation factor (VIF) across each construct of the model in order to detect the constructs that are highly correlated. HAIR, RINGLE AND SARSTEDT (2011) suggested that a tolerance value of 0.20 or lower and a VIF value of 5 and higher indicate a potential problem of multi-collinearity. Table 3 shows the result of the collinearity statistics (VIF) of the constructs in the hierarchical model component of the overall research model. As shown 
in the table, all the reported VIFs are less than 5, as HAIR et al. (2011) recommended. This shows that the degree of multi-collinearity among the constructs is not severe.

Table 3

Collinearity statistics (VIF) of the hierarchical model

\begin{tabular}{llll}
\hline & Bqst_Mot & Fin_Beh & Soc_Inf \\
\hline LB & 1.2880 & & \\
\hline DB & 1.2880 & & \\
\hline IB & & 1.3173 & \\
\hline SB & 1.3173 & 1.5852 \\
\hline FI & & 1.5852 \\
\hline CI & & & \\
\hline
\end{tabular}

Source: own study.

\subsection{Validity and reliability of second-order constructs}

\subsubsection{Convergent validity}

Table 4 shows the loadings of the respective indicators on their respective constructs of the research model. As shown in the table, except for four items (BM1, BM2, PA1 and FB2), all the loadings meet the recommended 0.7 threshold. This shows that the indicators of each construct were highly correlated with their respective construct, thus indicative of convergent validity.

To further verify the convergent validity of the measurement model, further analysis to determine the composite reliability and the AVEs of the latent constructs was conducted. As indicated in Table 3, the values of composite reliability, which measures the extent to which the indicators depict the latent construct, were all higher than the recommended minimum threshold of 0.7. Similarly, the reported AVEs showed that all values meet the minimum threshold of 0.5 (HAIR et al. 2014). Therefore, the requirement for convergent validity was achieved.

Table 4

Reliability and validity of constructs

\begin{tabular}{|c|c|c|c|c|}
\hline Code & Statement & Loadings & AVE & $\mathrm{CR}$ \\
\hline INT1 & Supplement existing source of income & 0.8768 & \multirow{6}{*}{0.7605} & \multirow{6}{*}{0.9501} \\
\hline INT2 & House upgrading/repairs & 0.8521 & & \\
\hline INT3 & Pay-off existing mortgage loan & 0.8546 & & \\
\hline INT4 & Pay-off other debts & 0.9142 & & \\
\hline INT5 & Pay medical bills & 0.8537 & & \\
\hline INT8 & Settle unforeseen financial needs & 0.8794 & & \\
\hline ATT1 & A good deal & 0.8821 & \multirow{3}{*}{0.7520} & \multirow{3}{*}{0.9010} \\
\hline ATT2 & Beneficial & 0.8638 & & \\
\hline ATT3 & Useful & 0.8555 & & \\
\hline INF_R1 & Children & 0.7659 & \multirow{7}{*}{0.5748} & \multirow{7}{*}{0.9043} \\
\hline INF_R2 & Spouse & 0.7856 & & \\
\hline INF_R3 & Siblings & 0.7137 & & \\
\hline INF_R4 & Parents & 0.7464 & & \\
\hline INF_R5 & Financial advisor & 0.7388 & & \\
\hline INF_R6 & Peers & 0.7899 & & \\
\hline INF_R7 & Community/religious leaders & 0.7437 & & \\
\hline BM1 & $\begin{array}{l}\text { I plan to leave my house as bequest to my } \\
\text { children }\end{array}$ & 0.6496 & \multirow{3}{*}{0.5368} & \multirow{3}{*}{0.8898} \\
\hline BM2 & I will leave my house to my children & 0.6925 & & \\
\hline BM3 & $\begin{array}{l}\text { My children expect me to leave my house for } \\
\text { them to inherit }\end{array}$ & 0.8237 & & \\
\hline
\end{tabular}




\begin{tabular}{|c|c|c|c|c|}
\hline BM4 & $\begin{array}{l}\text { I would be ashamed not to leave my house to } \\
\text { my children to inherit }\end{array}$ & 0.7118 & & \\
\hline BM5 & I have no children to leave my house to & 0.7326 & & \\
\hline BM6 & $\begin{array}{l}\text { My children can only inherit my house if they } \\
\text { help me while I am alive }\end{array}$ & 0.7633 & & \\
\hline BM7 & $\begin{array}{l}\text { My children will/are already self-sufficient and } \\
\text { do not care if I sell my house }\end{array}$ & 0.7153 & & \\
\hline PA1 & I own my house free of any housing loan debt & 0.6496 & \multirow{4}{*}{0.6118} & \multirow{4}{*}{0.8628} \\
\hline PA2 & I have almost paid off my housing loan & 0.7525 & & \\
\hline PA3 & $\begin{array}{l}\text { I am free to enter into a reverse mortgage } \\
\text { transaction }\end{array}$ & 0.7467 & & \\
\hline PA4 & I have absolute control over my house & 0.7843 & & \\
\hline SPA2 & I am very attached to my neighborhood & 0.8866 & \multirow{7}{*}{0.7140} & \multirow{7}{*}{0.9457} \\
\hline SPA3 & I identify strongly with my neighborhood & 0.8626 & & \\
\hline SPA4 & $\begin{array}{l}\text { I have a special bond with my neighborhood } \\
\text { and the people living in the area }\end{array}$ & 0.8691 & & \\
\hline SPA5 & $\begin{array}{l}\text { I derive more pleasure living in my house than } \\
\text { any other house }\end{array}$ & 0.7870 & & \\
\hline SPA6 & $\begin{array}{llll}\text { I am completely satisfied with my } \\
\text { accommodation }\end{array}$ & 0.7722 & & \\
\hline SPA7 & $\begin{array}{l}\text { Living in my neighborhood is more important } \\
\text { than any other neighborhood }\end{array}$ & 0.8918 & & \\
\hline SPA8 & I will not relocate from this neighborhood & 0.8378 & & \\
\hline FB1 & $\begin{array}{l}\text { I am saving for long term goal such as a car, } \\
\text { education or home }\end{array}$ & 0.8068 & \multirow{6}{*}{0.6181} & \multirow{6}{*}{0.9062} \\
\hline FB2 & I have maintained an emergency savings fund & 0.6922 & & \\
\hline FB3 & I save money from every monthly income & 0.7291 & & \\
\hline FB4 & $\begin{array}{l}\text { I have obtained or maintained adequate health } \\
\text { insurance }\end{array}$ & 0.8414 & & \\
\hline FB5 & $\begin{array}{l}\text { I have obtained or maintained adequate } \\
\text { property insurance }\end{array}$ & 0.8166 & & \\
\hline FB6 & $\begin{array}{l}\text { I have obtained or maintained adequate life } \\
\text { insurance }\end{array}$ & 0.8159 & & \\
\hline
\end{tabular}

Source: own study.

\subsubsection{Discriminant validity}

Table 5 shows the discriminant validity result using the Fornell-Larcker criterion. Based on this criterion, discriminant validity is said to be achieved when the square root of the AVE of the construct of interest is greater than any correlation between the construct and other constructs in the model (ALI et al. 2016). As shown in the Table, the square root of the AVE of each construct is higher than the inter-correlations between other constructs in the model, thus discriminant validity was achieved.

Table 5

Discriminant validity

\begin{tabular}{|c|c|c|c|c|c|c|}
\hline & Bqst_Mot & Fin_Beh & Intent & Perc_Abty & Attitude Plac_Att & Soc_Inf \\
\hline Bqst_Mot & 0.729 & & & & & \\
\hline Fin_Beh & -0.176 & 0.786 & & & & \\
\hline Intent & 0.470 & -0.268 & 0.867 & & & \\
\hline Perc_Abty & 0.386 & -0.071 & 0.418 & 0.785 & & \\
\hline Attitude & 0.122 & -0.068 & 0.431 & 0.301 & 0.854 & \\
\hline
\end{tabular}




\begin{tabular}{llllllll}
\hline Plac_Att & 0.268 & 0.091 & 0.396 & 0.184 & 0.052 & 0.847 & \\
\hline Soc_Inf & 0.188 & 0.080 & 0.342 & 0.321 & 0.451 & 0.016 & 0.755 \\
\hline
\end{tabular}

Source: own study.

Furthermore, in order to further verify the attainment of discriminant validity, the HTMT approach was also used. The HTMT approach is regarded as a more conservative and the most appropriate criterion for assessing discriminant validity (Henseler et al., 2015). The decision rule for establishing discriminant validity in the HTMT approach is for all inter-correlations between the construct of interest and the remaining constructs to be less than $0.085\left(\mathrm{r}<\mathrm{HTMT}_{0.85}\right)$ (HENSELER et al. 2014, KLINE 2011). Table 6 shows the result of the HTMT ratio in respect of the constructs in the research model. All the values reported were less than the $\mathrm{HTMT}_{0.85}$ criterion, which further supports the attainment of discriminant validity.

Table 6

Heterotrait-Monotrait Ratio (HTMT)

\begin{tabular}{llllllll}
\hline & Bqst_Mot & Fin_Beh & Intent & Perc_Abty & Attitude & Plac_Att & Soc_Inf \\
\hline Bqst_Mot & & & & & & \\
\hline Fin_Beh & 0.224 & & & & & \\
\hline Intent & 0.524 & 0.326 & & & & \\
\hline Perc_Abty & 0.457 & 0.154 & 0.462 & & & \\
\hline Attitude & 0.167 & 0.108 & 0.445 & 0.314 & & \\
\hline Plac_Att & 0.310 & 0.314 & 0.419 & 0.218 & 0.082 & \\
\hline Soc_Inf & 0.327 & 0.144 & 0.367 & 0.392 & 0.506 & 0.171 & \\
\hline
\end{tabular}

Source: own study.

\subsection{Structural Model Evaluation}

We began the evaluation of the structural model by determining the effect of the six exogenous constructs on the endogenous construct through the estimation of path coefficients in the research model. Table 7 shows the path coefficients $(\beta)$ with their respective $t$-values, $p$-values and $f^{2}$ values. As shown in the table, five paths show significant positive relationships while only one path shows a negative significant relationship. The highest positive significant path relationship was between Place Attachment and Reverse Mortgage Use Intention $(\beta=0.3263, t=9.5877)$, while the least positive significant path relationship was between Perceived Ability and Reverse Mortgage Use Intention $(\beta=0.1149, t=2.9593)$. Similarly, Bequest Motive and Social Influence reported positive and significant relationships with reverse mortgage use intention with path estimates of $(\beta=-0.2217, t=6.1273)$ and $(\beta=-0.1622, t=4.3596)$ respectively. The results suggest that individual intention to use reverse mortgage is positively influenced by the sense of attachment to a place, attitude towards the product, bequest motive, perceived social influence and the perceived ability to enter into a reverse mortgage contract. On the other hand, the path relationship between Financial Behavior and Reverse Mortgage Use Intention shows a negative significant path relationship $(\beta=-0.2345, t=6.5173)$.

After estimating the path coefficients, the next stage of structural model evaluation involves the determination of the model's coefficient of determination. The coefficient of determination (R-square) is the global measure of the structural model's predictive accuracy. It is an indication of the combined effects of all the exogenous latent constructs on the endogenous construct of the model. R-square also represents the amount of variance in the endogenous latent construct explained by all the exogenous latent constructs in the structural model (Hair, et al. 2014). The result shown in Table 7 indicates that all six exogenous constructs in the structural model have a moderate effect on the endogenous latent construct $\left(R^{2}=.53\right)$. This shows that the combined effect of the exogenous latent constructs explains about 53 percent of the variance in the endogenous latent construct, suggesting that attitude, bequest motive, social influence, perceived ability, sense of place attachment and financial behavior collectively predict an individual's willingness to use reverse mortgage.

The $f^{2}$ measures the change in $\mathrm{R}^{2}$ resulting from the omission of a specific exogenous construct in a model. It is used to assess the impact of individual exogenous constructs on the $\mathrm{R}^{2}$ value of the 
endogenous construct (Hair, et al. 2014). The effect size is measured according to Cohen's (1988) guidelines, where $f^{2}$ values of $0.02,0.15$ and 0.35 are considered small, medium and large effects, respectively. The $f^{2}$ values of the respective path relationships in the structural model are presented in Table 7. The results indicate that a sense of place attachment has a moderate impact on reverse mortgage use intention ( $\left.f^{2}=0.2048\right)$. It is followed by attitude $\left(f^{2}=0.1199\right)$ and financial behavior $\left(f^{2}=0.1078\right)$, which were slightly below the moderate impact benchmark but higher than the small impact threshold. The $f^{2}$ value for perceived ability shows that the construct has a small impact on the R-square value, while the impact of social influence and bequest motive were mid-way between small and medium impact. Thus, based on these results, all the six research hypotheses were supported.

Table 7

Result of structural model evaluation and hypothesis testing

\begin{tabular}{llllllll}
\hline Hypotheses & Paths & Beta & t-statistic & p-values & Decision & $f^{2}$ & $\mathrm{R}^{2}$ \\
\hline H1 & Attitude $\rightarrow$ Intent & 0.262 & 7.5105 & 0.0000 & Supported & 0.1199 \\
\hline H2 & Bqst_Mot $\rightarrow$ Intent & 0.234 & 6.1273 & 0.0000 & Supported & 0.0808 \\
\hline H3 & Soc_Inf $\rightarrow$ Intent & 0.155 & 4.3596 & 0.0000 & supported & 0.0411 \\
\hline H4 & Fin_Beh $\rightarrow$ Intent & -0.242 & 6.5173 & 0.0000 & Not Supported & 0.1078 \\
\hline H5 & Perc_Abty $\rightarrow$ Intent & 0.123 & 2.9593 & 0.0031 & Supported & 0.0216 \\
\hline H6 & Plac_Att $\rightarrow$ Intent & 0.317 & 9.5877 & 0.0000 & Supported & 0.2048 \\
\hline
\end{tabular}

Source: own study.

\section{Discussion and conclusion}

\subsection{Summary of findings}

The study set out to identify the factors that may influence individuals' willingness to use reverse mortgage in old-age by adopting the theory of planned behavior as its underlying theory. The findings show that attitude, bequest motive, social influence, perceived ability and sense of place attachment positively affect an individual's willingness to apply for reverse mortgage in old-age. On the other hand, financial behavior negatively affects willingness to apply for reverse mortgage. As revealed by the result, the sense of attachment to a place had the largest effect on willingness to apply for reverse mortgage. This supports the findings of previous studies where reverse mortgage applicants were found to indicate a high desire to continue living in their present accommodation (CHinloy, Megbolugbe 1994; CocCO, LOPEs 2015; DOling 2010; LuIZ, STOBIE 2010).

The result also showed that attitude significantly affects willingness to use reverse mortgage. This confirmed the findings of AlAM et al. (2012), ALLEYNE and BROOME (2010), NosI et al. (2014); PUTIT and JOHAN (2015), all of whom found that attitude significantly influences an individual's intention to engage in a particular financial behavior. Juxtaposing this in the context of the reverse mortgage product market, ZHOU (2014) reported a negative attitude towards reverse mortgage as one of the factors that hindered the growth in the demand for this product. In respect to bequest motive, however, the findings of this study contradict the general belief in the reverse mortgage body of knowledge. Whereas the result shows that bequest motive has a significant positive influence on the respondents' willingness to use reverse mortgage, previous studies had revealed otherwise. For instance CHOU et al. (2006), YOO and KOO,(2008) and ZHOU (2014) all reported that bequest motive negatively affect an individuals' willingness to apply for reverse mortgage.

Social influence was also found to have a positive effect on the willingness to use reverse mortgage. The result is in line with the findings of previous studies in the financial service industry that used TPB as the underlying theory in investigating the determinants of intention (AHMAD 2014; HANUDIN et al. 2011; SHANMUGHAM, RAMYA 2012; WAHYUNI 2012). In the context of this study, support from family members and the perceived attitude of the community about one's decision to apply for a reverse mortgage could affect the extent of individuals' willingness to do so. Financial behavior was shown to have a negative effect on reverse mortgage use intention. This contradicts the findings of CHOU et al. (2006) and DAVIDOFF et al. (2014), both of which found that individuals who engage in other financial practices, such as financial management and investment, were shown to be 
more attracted to reverse mortgage. The negative relationship between financial behavior and reverse mortgage use intention might be surprising since participation in a reverse mortgage transaction is also considered to be a facet of financial behavior. However, when looking at the questions in the questionnaire, the respondents rated highly on the saving motive and financial planning scales that measured financial behavior, which implies that they subjectively considered themselves better off in terms of financial security in later life.

\subsection{Theoretical implication}

Previous research on reverse mortgage focused on the of the potential demand for the product and the investigation of the differences between hypothesized and actual market sizes (BISHOP, SHAN 2008; CAPLIN 2001; LEVITON 2002; ONG 2008; VENTI, WISE 1989). However, most of these works simulated the level of potential demand based on regional or nationwide census data. The results of such simulations, in most cases, revealed a promising future for the reverse mortgage product, with a potential of providing hundreds of thousands of elderly households the opportunity to consume their housing equity. However, the reality of the reverse mortgage product market left many unanswered questions regarding the identified wide gap between the theoretical market size and the actual demand for the product since its inception about four decades ago in the United States. Thus, applying a behavioral change theory, such as the TPB, might offer new insight into the dynamics of the reverse mortgage market, thereby unlocking the opportunity to use social behavioral theories to uncover the mysteries bedeviling reverse mortgage market growth.

\subsection{Practical implication}

One of the cardinal points of the Malaysian government, as contained in the $10^{\text {th }}$ Malaysian Plan and the New Economic Model (NEM), is to ensure inclusiveness in all its policies. By understanding the attitude of the elderly towards reverse mortgage, the government will be provided with necessary information that can be used in formulating policies and laws supporting the provision of the elderly with compliant products and services. Similarly, financial institutions will find the outcome of this study beneficial in that it will provide them with information on the attitude of the elderly towards the reverse mortgage product. By understanding the customers' line of thinking and perception, the financial institution will be able to design new reverse mortgage products by putting into consideration those socio-cultural and behavioral factors that can influence product choice among potential consumers. Access to information about the customers' attitude will aid financial institutions in designing marketing strategies that will ensure high patronage and thereby high profitability.

\section{References}

Abd SAmad S., MANSOR N., 2013, Population Ageing and Social Protection in Malaysia, Malaysian Journal of Economic Studies, 50(2), 139-156,

Ahmad N. H. B., 2014, Determinants of Customers' Intention to Use Islamic Personal Finance, University Utara Malaysia,

AJZEN I., 1991, The theory of planned behavior, Orgnizational Behavior and Human Decision Processes, 50, 179-211. https://doi.org/10.1016/0749-5978(91)90020-T.

Alam S. S., JANOR H., ANIZA C., Wel C., 2012, Is Religiosity an Important Factor in Influencing the Intention to Undertake Islamic Home Financing in Klang Valley?, World Applied Sciences Journal 19 (7): 1030-1041,

Alavi K., 2013, Intergenerational Relationships Between Aging Parents and Their Adult Children in Malaysia, 20th Association of Asian Social Science Research Councils (AASSREC) Biennial General Conference, April, 1-19,

AlI F., KIM G. W., RYU, K., 2016, The Effect of Physical Environment on Passenger Delight and Satisfaction: Moderating Effect of National Identity. Tourism Management, 57, 213-224, retrieved from http://dx.doi.org/10.1016/j.tourman.2016.06.004,

AlLEYNE P., BROOME T., 2010, An Exploratory Study of Factors Influencing Investment Decisions of Potential Investors, CBB Working Paper, Barbados,

Alma'AMun S., 2012, Searching for Bequest Motives and Attitudes to Leaving a Bequest among Malaysian Muslims, Jurnal Ekonomi Malaysia, 46(1), 73-84,

Amin H., 2013, Factors Influencing Malaysian Bank Customers to Choose Islamic Credit Cards: Empirical Evidence from the TRA Model. Journal of Islamic Marketing, 4(3), 245-263, retrieved from 
http:/ /www.emeraldinsight.com/10.1108/JIMA-02-2012-0013,

AMiN H., ABDUl RAHMAN A. R., ABDUL RAZAK D., 2014, Consumer Acceptance of Islamic Home Financing, International Journal of Housing Markets and Analysis, 7(3), 307-332, retrieved from http://www.emeraldinsight.com/doi/abs/10.1108/IJHMA-12-2012-0063,

BECKER J., KLEIN K., WeTZELS M., 2012, Hierarchical Latent Variable Models in PLS-SEM: Guidelines for Using Reflective-Formative Type Models, Long Range Planning, 45(5-6), 359-394,

Bishop T., SHAN H., 2008, Reverse Mortgages: A Closer Look at HECM Loans, National Bureau for Economic Research, 1-51, retrieved from http:/ / scholar.google.com/scholar?hl=en\&btnG=Search\&q=intitle:

Reverse+Mortgages+:+A+Closer+Look+at+HECM+Loans\#0,

CAPLIN A., 2001, The Reverse Mortgage Market: Problems and Prospects, In O. S. Mitchell, Z. Bodie, B. Hammond, S. Zeldes (Eds.), Innovations in Retirement Financing, Pension Research Council,

Chinloy P., Megbolugbe I. F., 1994, Reverse Mortgages - Contracting and Crossover Risk, Journal of the American Real Estate and Urban Economics Association, 22(2), 367-386. https:// doi.org/10.1111/1540-6229.00638,

CHOU K. L., CHOW N. W. S., CHI I., 2006, Willingness to Consider Applying for Reverse Mortgage in Hong Kong Chinese Middle-aged Homeowners, Habitat International, 30(3), 716-727,

ChuAn C. S., SeOng L. C., Chau W. H., 2014, Financial Satisfaction, Resource Transfers and Bequest Motives A mong Malaysia's Urban Older Adults, In Proceedings Book of ICETSR, Handbook on the Emerging Trends in Scientific Research (Vol. 8, pp. 106-129), PAK Publishing Group,

COCCO J. F., LOPES P., 2015, Reverse Mortgage Design, LBS/LSE Working Paper,

DAVIDOFF T., GERHARD P., POST T., 2017, Reverse Mortgages: What Homeowners (Don't) Know and How it Matters, Journal of Economic Behavior and Organization, 133, 151-171,

DAVIS F. D., BAGOZZI R. P., WARSHAW P. R., 1992, Extrinsic and Intrinsic Motivation to Use Computers in the Wokplace, Journal of Applied Social Psychology, 22(14), 1111-1132. https:// doi.org/10.1111/j.1559-1816.1992.tb00945.x

Department of Statistics Malaysia, 2012, Household Income and Basic Amenities Survey Report, Kuala Lumpur, retrieved from http:/ / www.newss.statistics.gov.my,

Doling J., 2010, Releasing Housing Equity, DEMHOW-Project Funded under the Socio-Economic Sciences and Humanities, Demographic Change and Housing Wealth,

Employee Provident Fund, 2015, EPF Savings and your Retirement, Kuala Lumpur: Employee Provident Fund,

FORNERO E., ROSSI M. C., BRANCATI M. C. U., 2011, Explaining Why, Right or Wrong,(Italian) Households do not Like Reverse Mortgages, Journal of Pension, 1-23. https:// doi.org/10.1017/S1474747215000013,

FratantONI M., 1999, Reverse Mortgage Choices: A Theoretical and Empirical Analysis of the Borrowing Decisions of Elderly Homeowners, Journal of Housing Research, 10(2), 189-208, retrieved from http://ares.metapress.com/index/K0736X187532876T.pdf,

GotMAN A., 2011, Towards the End of Bequest? The Life Cycle Hypothesis Sold to Seniors: Critical Reflections on the Reverse Mortgage Financial Fashion, Civitas - Journal of Social Sciences, 11(1), 93114 ,

HAFFNER M. E. A., ONG R., WoOD G.A., 2015, Mortgage Equity Withdrawal in Australia: Recent Trends, Institutional Settings and Perspectives, OTB Working Paper, No. 2015-2, Delft, The Netherlands.

Hair J. F., Black W. C., Babin B. J., ANDerson R. E., 2010, Multivariate Data Analysis (7th ed.). Eaglewood Cliff, NJ: Prentice Hall,

Hair, J. F., Hult, G. T. M., Ringle, C. M., \& Sarstedt, M. (2014). A Primer on Partial Least Squares Structural Equation Modeling (PLS-SEM). Thousand Oaks, Califonia: Sage Publications,

HAIR J. F., Ringle C. M., SARSTEDT M., 2011, PLS-SEM: Indeed a Silver Bullet, Journal of Marketing Theory and Practice, 19(2), 139-151, https:/ / doi.org/10.2753/MTP1069-6679190202,

Hamid T. A., 2015, Population Ageing in Malaysia: A Mosaic of Issues, Challenges and Prospect, Kuala Lumpur: Universiti Putra Malaysia Press,

HANEWAld K., POST T., SHerris M., 2016, Portfolio Choice in Retirement What Is the Optimal Home Equity Release Product? The Journal of Risk and Insurance, 83(2), 421-446, retrieved from http:/ / papers.ssrn.com/sol3/ papers.cfm?abstract_id=2407680,

Hanudin A., Abdul Rahim A. R., StePhen L. S. J., ANG MAgDalene C. H., Amin H., RAhMAn A. R. A., 
... HwA A. M. C., 2011, Determinants of customers' intention to use Islamic personal financing: The case of Malaysian Islamic banks, Journal of Islamic Accounting and Business Research, 2(1), 22-42,

Hashemnezhad H., Heidari A. A., Hoseini P. M., 2013, "Sense of Place" and "Place Attachment.", International Journal of Architecture and Urban Development, 3(1), 5-12,

Help Age International \& UNFPA, 2012, Ageing in the Twenty-First Century: A Celebration and a Challenge, https://doi.org/978-0-89714-981-5.

Henseler J., Ringle C. M., SARSTEDT M., 2015, A New Criterion for Assessing Discriminant Validity in Variance-based Structural Equation Modeling, Journal of the Academy of Marketing Science, 43, 115135,

Hot N. K., 2013, The Prospects for Old-age Income Security in Hong Kong and Singapore. London School of Economics and Political Science, retrieved from http://etheses.lse.ac.uk/786/1/Ng_Prospects_ for_old-age_income_security_in_Hong_Kong_and_Singapore_2013.pdf,

JORGENSEN B. S., STEDMAN R. C., 2001, Sense of Place as an Attitude: Lakeshore Owners Attitude Towards their Properties, Journal of Environmental Psychology, 21, 233-248. https://doi.org/10.1006/jevp.2001.0226,

KemPSON E., COllard S., MOORE N., 2005, Measuring Financial Capability: an Exploratory Study. Financial Service Authority. London,

KenNeDy B. P., 2013, The Theory of Planned Behavior and Financial Literacy: A Predictive Model for Credit Card Debt? Marshall University. https:// doi.org/Paper 480,

KNAPP K., 2001, The Influence of Family and Community Ties on the Demand for Reverse Mortgages, ILC Research Report, New York,

Kolm S. C., 2006, Introduction to the Economics of Giving, Altruism and Reciprocity, In J. M. Y. SergeChristophe Kolm (Ed.), Handbook of the Economics of Giving, Altruism and Reciprocity, vol. 1, pp. 1-122, North-Holland, https:/ / doi.org/10.1016/S1574-0714(06)01001-3,

KumAR M., 2013, Reverse Mortgage as a Retirement Planning Tool: an Evaluation, Punjabi University,

Kumar P. M., DivaKaruni R. K., SRI VenKatA M., 2008, Reverse Mortgages - Features \& Risks, In 10th Global Conference of Actuaries, pp. 124-146, Mumbai: Institute of Actuaries of India, retrieved from https:/ / www.actuariesindia.org/subMenu.aspx?id=211\&val=10th_GCA,

LeE C.-C., CHEN K.-S., So-De SHYu D., 2015, Credit, Equity Conversion and Housing Endowment, Analysis of Reverse Mortgage Markets, Journal of Applied Finance \& Banking, 5(3), 63-80,

Leviton R., 2002, Reverse Mortgage Decision- Making, Journal of Aging \& Social Policy, 13(4), 1-16. https://doi.org/10.1300/J031v13n04,

LOKE Y. J., 2013, Household's Preparedness for Income Shock, in Singapore Economic Review Conference 2013, pp. 1-25,

Luiz J. M., Stobie G., 2010, The Market for Equity Release Products: Lessons from the International Experience, South African Business Review, 14(2), 24-45,

MAYER C. J., SimONS K. V., 1994, Reverse Mortgages and the Liquidity of Housing Wealth, Real Estate Economics, 22(2), 235-255,

MoHAMmed M. I., SUlaiman N., 2017a, Determinants of Reverse Mortgage Use Intention: a Thheoretical Framework, International Research Journal of Management and Commerce, 4(2), 153-178,

Mohammed M. I., Sulaiman N., 2017b, Prospect of Developing Reverse Mortgage Product in Malaysia: A SWOT Analysis, International Journal of Business Management, 2(4), 1-17,

Mohammed M. I., Sulaiman N., ADAmu D. (In press.), Dimensionality and Reliability of the Determinants of Reverse Mortgage Use Intention, Path of Science,

NiciŃSKA A., 2013, Why do People Bequeath? Argumenta Oeconomica, 2(31), 75-95,

Nosi C., D'Agostino A., Maria PAgliucA M., Alberto Pratesi C., 2014, Saving for Old Age: Longevity Annuity Buying Intention of Italian Uoung Adults, Journal of Behavioral and Experimental Economics, 51, 85-98. https:// doi.org/10.1016/j.socec.2014.05.001,

ONG R., 2008, Unlocking Housing Equity Through Reverse Mortgages: The Case of Elderly Homeowners in Australia, European Journal of Housing Policy, 8(1), 61-79,

Ong R., Wood G. A., Austen, S., JefFerson T., HAFfNer M. E. A., 2015, Housing Equity Withdrawal in Australia: Prevalence, Patterns and Motivations in Mid-to-late Life, Housing Studies, 3037(April), 1-24, https://doi.org/10.1080/02673037.2015.1009875,

Putit L., Johan Z. J., 2015, C onsumers' Acceptance of "Halal" Credit Card Services : An Empirical Analysis, Journal of Emerging Economies and Islamic Research, 3(1), 1-9,

Rasmussen D. W., Megbolugbe I. F., Morgan B. A., 1995, Using the 1990 Public Use Microdata Sample to 
Estimate Potential Demand for Reverse Mortgage Products, Journal of Housing Research, 6(1), 1-23,

REDFOOT D. L., SCHOLEN K., BROWN S. K., 2007, Reverse Mortgages: Niche Product or Mainstream Solution? Report on the 2006 AARP National Survey of Reverse Mortgage Shoppers, Washington D.C.,

REED R., GIBLER, K., 2003, The Case for Reverse Mortgages in Australia - Applying the USA Experience, Real Estate Society Conference, Brisbane, Australia, (January, 19-22, retrieved from http:// prres.net/ Papers/Reed_Gibler_The_Case_for_Reverse_Mortgages_in_Australia_Applying_the_USA_Experi ence.pdf,

Sau Po Centre on Ageing, 2010, Report on a Study on Reverse Mortgage Commissioned by the The Hong Kong Mortgage Corporation Limited. Hong Kong,

SHAN H., 2011, Reversing the trend: The recent expansion of the reverse mortgage market, Real Estate Economics, 39(4), 743-768, https://doi.org/10.1111/j.1540-6229.2011.00310.x,

SHANMUGHAM R., RAMYA K., 2012, Impact of Social Factors on Individual Investors' Trading Behaviour, Procedia Economics and Finance, 2(Af), 237-246, https:/ / doi.org/10.1016/S2212-5671(12)00084-6.

Slatten L. A. D., 2010, An Application and Extension of the Technology Acceptance Model to Nonprofit Certification, Journal For Nonprofit Management, 14(1), 47-55,

TABACHNick B. G., FidelL L. S., 2013, Using Multivariate Statistics (6th ed.), Boston, Person,

TAIB F. M., RAMAYAH T., RAZAK D. A., 2008, Factors Influencing Intention to Use Diminishing Partnership Home Financing, International Journal of Islamic and Middle Eastern Finance and Management, 1(3), 235-248,

The World Bank, 2014, Malaysia Economic Monitor: Towards a Middle-class Society, retrieved from http://documents.worldbank.org/curated/en/2014/12/23035132/malaysia-economic-monitortowards-middle-class-society,

Toussaint J., Szemzo H., Elsinga M., Hegedüs J., Teller N., 2012,. Owner-occupation, Mortgages and Intergenerational Transfers: The Extreme Cases of Hungary and the Netherlands, International Journal of Housing Policy, 12(1), 69-90, https:/ / doi.org/10.1080/14616718.2012.651327,

United Nations Department of Economic and Social Affairs Population Division, 2013, World Population Ageing 2013. ST/ESA/SER.A/348, New York, https://doi.org/ST/ESA/SER.A/348.

VenKATESH V., DAVIS F. D., 2000, A Theoretical Extension of the Technology Acceptance Model: Four Longitudinal Field Studies, Management Science, 46(2), 186-204,

Venti S. F., Wise D. A., 1989, Aging, Moving, and Housing Wealth, in The Economics of Aging, pp. 9-54, https:// doi.org/10.3386/w2324,

WAHYUNI S., 2012, Moslem Community Behavior in The Conduct of Islamic Bank: The Moderation Role of Knowledge and Pricing, Procedia - Social and Behavioral Sciences, 57, 290-298, https://doi.org/10.1016/j.sbspro.2012.09.1188,

XIAO J. J., SORHAINDO B., GARMAN E. T., 2006, Financial Behaviours of Consumers in Credit Counselling, International Journal of Consumer Studies, 30(2), 108-121, https://doi.org/10.1111/j.14706431.2005.00455.x,

YeAP J. A. L., RAMAYAH T., SOTO-Acosta P., 2016, Factors Propelling the Adoption of M-learning Among Students in Higher Education, Electronic Markets, 26(4), 323-338,

YoO I., KOO I., 2008, Do Children Support Their Parents ' Application for the Reverse Mortgage ?: A Korean Case, no. 8-3, KDI School Working Paper Series, Seoul, retrieved from http:/ / papers.ssrn.com/sol3/ papers.cfm?abstract_id=1095549.

ZHOU H., 2014, Analysis on Demand Factor of Regional Difference for Reverse Mortgage-based on Survey Data in Beijing \& Hangzhou, Journal of Chemical and Pharmaceutical Research, 6(5), 232-238,

Zin R. H. M., Lee H. A., Abdul-Rahman S., 2002, Social Protection in Malaysia, in E. Adam, M. von Hauff, M. John (Eds.), Social Protection in Southeast and East Asia, pp. 119-169, Singapore: Friedrich Ebert Stiftung. 